10. Roshchyna, L.O. and Horbatenko, O.V., 2014. Rozkoly ta ob'yednannya khrystyyanbaptystiv u radyans'ku dobu [The splitting and unification of Baptist Christians in the Soviet era]. Science. Religion. Society. «Science and Education» Institute of Artificial Intelligence, 3(59), pp. 16-22.

11. Savynskyy, S., 2011. Razdelenye y ob'edynenye v ystoryy Evanhel'sko-baptystskoho bratstva [Separation and Unification in the History of the Evangelical Baptist Brotherhood]. The guest, 2, pp. 8-13.

УДК 659.4:37.015.31-057.87:377

DOI:10.31339/2617-0833-2020-1(28)-28-31

ФОРМУВАННЯ МЕДІАГРАМОТНОСТІ У СТУДЕНТІВ КОЛЕДЖУ

Малеш М.Ю., Хом’як Б.Я.

\title{
THE DEVELOPMENT OF MEDIA LITERACY AMONG THE COLLEGE STUDENTS
}

Malesh Marina, Khomiak Bohdan

Автори статті дослідили рівень медіаграмотності у студентів коледжу і розробили комплекс занять щзодо розуміння та використання медіа, комунікації за допомогою медіазасобів та вміння досягати власних иілей, застосовуючи медіа. Впровадження иього комплексу занять дозволить вирішити проблему формування медіаграмотності у студентів та сприятиме розвитку у майбутніх фахівців медіакомтетентності.

Ключові слова: медіаосвіта, медіакультура, медіаграмотність, медіакомпетентність.

The authors of the article have researched the level the media literacy of college students and developed a set of classes on understanding and using media, communication through media and the ability to achieve their own goals using media. The implementation of this set of classes will solve the problem of forming media literacy in students and promote the development of media literacy among future professionals.

Key words: media education, media culture, media literacy, media competence.

Вміле застосування інформаційно-комунікаційних технологій в сучасному суспільстві $€$ пріоритетним напрямком розвитку особистості. Особливо це стосується молодого покоління, яке щоденно використовує смартфони та інші гаджети як в освітньому процесі, так i в розважальних цілях. Постійне перебування у віртуальному просторі та перевантаження інформаційним контентом вимагає від студентів коледжу вдосконалення як комп'ютерної, так і медіаграмотності.

Майбутні фахівці під час навчання у коледжі мають здобути медіаосвіту, навчитися ефективно взаємодіяти 3 інформаційними потоками та адекватно поводитися в інформаційному середовищі, щоби стати конкурентоспроможними на ринку праці. Проблемі формування медіаграмотності останнім часом приділяється багато уваги. Такі вітчизняні науковці як Власенко I.А. та Олійник М.С. розробили тренінгову програму «Я медіаграмотний», яка містить блоки спрямовані на усвідомлення впливу засобів масової інформації на людину, формування навичок пошуку і критичного аналізу матеріалів масмедіа та закріплення відповідних навичок [1]. Авторами Павленко І.Г. та Курліщук I.І. для вирішення проблеми формування медіаграмотності студентів був розроблений факультативний навчальний курс «Засоби масової комунікації і сучасність». Впровадження цього навчального курсу в освітній процес закладу вищої освіти сприятиме підготовці фахівців, які вміють критично аналізувати наявні медіаресурси, створювати нові і здатні до 
самостійної творчої діяльності в медіапросторі $[2,3]$. Іванов В.Ф. та Шкоба О.Я. дослідили значення терміну медіаграмотність та сформували думку, що «метою медіаосвіти визнається досягнення медіаграмотності» [4].

Згідно Концепції впровадження медіаосвіти в Україні під терміном «медіаосвіта» розуміють частину освітнього процесу, спрямовану на формування в суспільстві медіакультури, підготовку особистості до безпечної та ефективної взаємодії із сучасною системою масмедіа, включаючи як традиційні (друковані видання, радіо, кіно, телебачення), так і новітні (комп'ютерно опосередковане спілкування, інтернет, мобільна телефонія) медіа 3 урахуванням розвитку інформаційно-комунікаційних технологій. Тоді як «медіакультура»це культура сприймання i виробництва соціальними групами та соціумом у цілому сукупності інформаційно-комунікаційних засобів, що функціонують у суспільстві, знакових систем, технологій комунікації, пошуку, збирання, виробництва і передавання інформації. В свою чергу, «медіаграмотність» $\epsilon$ складовою медіакультури, яка стосується вміння користуватися інформаційно-комунікативною технікою, виражати себе і спілкуватися за допомогою медіазасобів, успішно здобувати необхідну інформацію, свідомо сприймати і критично тлумачити інформацію, отриману 3 різних медіа, відділяти реальність від іiі віртуальної симуляції, тобто розуміти реальність, сконструйовану медіаджерелами, осмислювати владні стосунки, міфи і типи контролю, які вони культивують. Тоді як «медіакомпетентність» відображає рівень медіакультури, що забезпечує розуміння особистістю соціокультурного, економічного і політичного контексту функціонування медіа, засвідчує іiі здатність бути носієм і передавачем медіакультурних цінностей, смаків i стандартів, ефективно взаємодіяти 3 медіапростором, створювати нові елементи медіакультури сучасного суспільства, реалізувати активну громадянську позицію [5].

Автори ставили за мету розробити комплекс занять, завдяки яким можна формувати високий рівень медіаграмотності у студентів коледжу.

Враховуючи той факт, що медіаграмотність має чотири рівні - розуміння роботи медіа, використання медіа, взаємодія з іншими через медіа та ефективне користування медіа [6], необхідно було з'ясувати на якому з цих рівнів знаходяться студенти першого курсу. Для цього нами було використано тест [7] та гру «25 запитань» [8]. Результати проведеного дослідження показали, що 18\% респондентів мають усвідомлення того, як працюють засоби масової інформації та медіа, як впливають на суспільство та яким чином викривляють реальність - 1 рівень; 42\% - вміло орієнтуються в медіасередовищі та мають технічні навички використання медіа - 2 рівень; 28 \% - вміють знайти й проаналізувати інформацію, створити власний контент і представляти його - 3 рівень; $12 \%$ - вміють досягати власні цілі через медіа, мають розуміння того, як медіа впливає особисто на них.

Отже, отримавши результати медіаграмотності студентів коледжу авторами було розроблено комплекс занять на основі десяти компетентностей медіаграмотності [9]. Для зручності ці компетентності зведені у таблицю і сформовано 10 занять, які були націлені на розвиток кожної з компетентності окремо (див. таблицю 1).

Таблиця 1.

10 компетентностей медіаграмотності

\begin{tabular}{|l|l|}
\hline \multirow{2}{*}{ Розуміння } & 1. Розуміння все більшого впливу ЗМІ на суспільство \\
\cline { 2 - 3 } & 2. Розуміння того, як побудовані ЗМІ \\
\cline { 2 - 3 } & 3. Розуміння того, як медіа забарвлюють реальність \\
\hline \multirow{2}{*}{ Використання } & 4. Використання обладнання, програмного забезпечення й додатків \\
\cline { 2 - 3 } & 5. Оріснтація в медіасередовищі \\
\hline \multirow{2}{*}{ Комунікація } & 6. Пошук та обробка інформації \\
\cline { 2 - 3 } & 7. Створення контенту. Теперішнє медіасуспільство - це суспільство 2.0 \\
\hline
\end{tabular}




\begin{tabular}{|l|l|}
\hline \hline & 8. Використання соціальних мереж \\
\hline \multirow{2}{*}{ Стратегія } & 9. Розмірковування про власне використання медіа \\
\cline { 2 - 3 } & $\mathbf{1 0 .}$ Досягнення цілей за допомогою засобів масової інформації \\
\hline
\end{tabular}

Впродовж навчального року зі студентами коледжу було проведено комплекс занять на розвиток компетентностей медіаграмотності, що сприяло не тільки формуванню медіаграмотності, а й покращенню рівня медіакультури тобто медіакомпетентність. Результатом нашого дослідження стало проведення підсумкового практичного заняття на створення власного проекту щодо ефективного використання медіаресурсів. Більшість студентів коледжу (68\%) розвинули свої вміння і навички роботи у розумінні, використанні, комунікації та стратегії, чим показали високий рівень медіаграмотності, лише $11 \%$ студентів опанували достатній рівень та $21 \%$ досягли середнього рівня.

Отриманий досвід показав, що розроблений комплекс занять на розвиток компетентностей медіаграмотності позитивно вплинув на формування медіаграмотності студентів коледжу. Перспективою подальших досліджень є розробка завдань для формування медіаграмотності студентів різних спеціальностей.

\section{Список використаних джерел}

1. Власенко I.А. Формування медіаграмотності студентів: практичний аспект / Власенко І.А., Олійник М.С. // Теорія і практика сучасної психології. - 2018. № 2. - С. 115 118.

2. Павленко І.Г. Медіаграмотність як складова інформаційної культури студентської молоді. - Режим доступу : http://mediaosvita.org.ua/book/ pavlenko-i-g-mediagramotnistyak-skladova-informatsijnoyi-kultury-studentskoyi-molodi/

3. Павленко І.Г. Формування медіаграмотності студентів в освітньому процесі вищого навчального закладу / I. Г. Павленко, I. I. Курліщук // Науковий часопис Національного педагогічного університету імені М. П. Драгоманова. Серія 5 : Педагогічні науки : реалії та перспективи : зб. наук. праць. - Київ : Вид-во НПУ імені М. П. Драгоманова, 2018. - Вип. 61. - С. 227-231.

4. Іванов В.Ф. Медіаосвіта та медіаграмотність: визначення термінів / Іванов В. Ф., Шкоба О. Я. // Інформаційне суспільство. Випуск 16. 2012. С. 41 - 52.

5. Концепція впровадження медіаосвіти в Україні (нова редакція). - Режим доступу : https://ms.detector.media/mediaosvita/post/16501/2016-04-27-kontseptsiyavprovadzhennya-mediaosviti-v-ukraini-nova-redaktsiya/

6. Портал медіаосвіта та медіаграмотність - Режим доступу: http://medialiteracy.org.ua/rozuminnya-media-osnovy-mediagramotnosti/

7. «Обираю свідомо!» - це інформаційно-просвітницька кампанія для підвищення рівня медіаграмотності та критичного мислення серед молодіжної аудиторії та виборців, які обирають вперше, шляхом поширення просвітницького контенту в соцмережах та 3МI / Тест «Перевір свій рівень медіаграмотності». - Режим доступу: http://idecide.com.ua/testmedialiteracy

8. Media IQ . - Режим доступу : http://media-iq.tilda.ws/

9. MediaSapiens. Бути медіаграмотним: десять необхідних компетентностей. - Режим доступу:https://ms.detector.media/mediaosvita/post/18961/2017-05-24-butimediagramotnim-desyat-neobkhidnikh-kompetentnostei/

\section{References}

1. Vlasenko, I. A., Olijny`k, M. S. 2018. Formuvannya mediagramotnosti studentiv: prakty chny $\mathrm{j}$ aspekt [Formation of media literacy of students: practical aspect]. Theory and practice of modern psychology. N. 2, P. 115-118. 
2. Pavlenko, I. G. Mediagramotnist` yak skladova informacijnoyi kul’tury` students`koyi molodi [Media literacy as a component of information culture of student youth]. Available at:http://mediaosvita.org.ua/book/pavlenko-i-g-mediagramotnist-yak-skladovainformatsijnoyi-kultury-studentskoyi-molodi/

3. Pavlenko, I. G., Kurlishhuk, I. I. 2018. Formuvannya mediagramotnosti studentiv v osvitn`omu procesi vy`shhogo navchal`nogo zakladu [Formation of media literacy of students in the educational process of higher education]. Scientific journal of the National Pedagogical University named after MP Drahomanov. N. 5, Pedagogical sciences: realities and prospects. N. 61. Ky`yiv. Vy`d-vo NPU imeni M. P. Dragomanova, P. 227-231.

4. Ivanov, V. F., Shkoba, O. Ya. 2012. Mediaosvita ta mediagramotnist: vy`znachennya terminiv [Media education and media literacy: definition of terms]. Information society. $\mathrm{N}$. 16, P. 41-52.

5. 2016. Koncepciya vprovadzhennya mediaosvity` v Ukrayini (nova redakciya) [The concept of introducing media education in Ukraine (new edition)]. Available at: https://ms.detector.media/mediaosvita/post/16501/2016-04-27-kontseptsiyavprovadzhennya-mediaosviti-v-ukraini-nova-redaktsiya/

6. Portal mediaosvita ta mediagramotnist' [Portal of media education and media literacy]. Available at. http://medialiteracy.org.ua/rozuminnya-media-osnovy-mediagramotnosti/

7. «Oby`rayu svidomo!» - ce informacijno-prosvitny`cz`ka kampaniya dlya pidvy`shhennya rivnya mediagramotnosti ta kry`ty`chnogo my`slennya sered molodizhnoyi audy`toriyi ta vy`borciv, yaki oby`rayut vpershe, shlyaxom poshy`rennya prosvitny`cz`kogo kontentu v soczmerezhax ta ZMI ["I choose consciously!" - is an informational and educational campaign to increase the level of media literacy and critical thinking among young audiences and voters who choose for the first time, by distributing educational content on social networks and the media]. Test "Check your level of media literacy". Available at: http://idecide.com.ua/testmedialiteracy

8. Media IQ. Available at: http://media-iq.tilda.ws/

9. Buty` mediagramotny`m: desyat neobxidny`x kompetentnostej [Being media literate: ten necessary competencies]. MediaSapiens. Available at: https://ms.detector.media/mediaosvita/post/18961/2017-05-24-buti-mediagramotnim-desyatneobkhidnikh-kompetentnostei/

УДК 338.48:911-047.58 (477.87) (045)

DOI:10.31339/2617-0833-2020-1(28)-31-39

\section{ЛАНДШАФТНО-ЕКОЛОГІЧНЕ ДОСЛІДЖЕННЯ ПРИАВТОМАГІСТРАЛЬНИХ ТЕРИТОРІЙ РЕГІОНУ}

Матвійчук Л.Ю., Лепкий М.І., Лужанська Т.Ю.

\section{LANDSCAPE-EKOLOGICAL STUDE AT AUTOBACKBONE TERRITORIES OF THE REGION}

Matviychuk Ludmila, Lepky Michael, Luzhanskaya Tetyana

У статті розкриваються питання актуальності проведення польових і лабораторних ландшафтно-екологічних досліджень основних приавтомагістральних смуг Волинської області. Досліджено методичні прийоми з метою оцінки накопичення важких металів у трунтах приавтомобільних магістралей. На основі обстеження екологічних полігонів встановлено ступінь забруднення хімічними елементами грунтово-рослинного покриву приавтомагістральних територій.

Ключові слова: придорожні автомобільні смуги, методи ландшафтно-екологічного 